\title{
John Gumperz's Data from Ziljska Bistrica: Some Corrections
}

\section{Introduction*}

Frequently cited as a model of sociolinguistic enquiry into language shift and code-switching is John Gumperz's Discourse Strategies (1982): there is hardly a textbook or an article dealing with these subjects which does not refer to the book with approval, if not with reverence. Some of the data cited by Gumperz are from the small, partly bilingual (Slovene/German) town of Ziljska Bistrica/Feistritz an der Gail in Carinthia, Austria [henceforward, ZB]; these data are to a significant degree incorrect. Here I correct the errors in the data; elsewhere (Priestly, in prep.) I set the record straight with respect to Gumperz's description of the sociolinguistic situation in $\mathrm{ZB}$ and discuss the import of the inaccuracies in that description, and of the errors in his data, on his conclusions with respect to language-shift and to code-switching. This is important: both his description and his data are taken at face value and accepted as accurate by the linguistic public; the fact that they are not accurate, and the extent to which they are not so, may affect his reliability and reputation as one of the luminaries of American sociolinguistics.

In three standard collections of articles on codeswitching - Heller (1988), Eastman (1992) and Milroy and Muysken (1995) - Gumperz is cited as an authority very frequently, and the citations are by well-known code-switching specialists such as Shana Poplack, Peter Auer, Monica Heller and Carol Myers-Scotton, and by reliable sociolinguists such as Kathryn Woolard, Susan Gal, and Lesley Milroy. The last-named, in her two important books of 1980 and 1987, cites Gumperz's work in Austria as exemplary in two respects: both his demonstration of the relevance of analysis of change in linguistic network patterns, and his methodology.

Moreover, Ronald Wardhaugh, in his well-known and thrice-reprinted sociolinguistic textbook (2004), who cites Gumperz as an authority on code-switching and on shared knowledge not only of codes but of their application, accepts as accurate Gumperz's inaccurate description of the verbal repertoire in ZB. So too, Lenore Grenoble (1995), in a laudable exhortation to Slavic linguists to practise sociolinguistics (something they had been very slow to do) quotes Gumperz to exemplify code-switching; and she chooses two examples from his data from ZB, one of which is linguistically inept. Wardhaugh and Grenoble had, unfortunately, no reason not to accept these data.

Even when Myers-Scotton (1993: 46, 51, 55) criticizes certain aspects of Gumperz's work, she nevertheless writes that he was "the most influential figure in discussions of the social motivations for [code-switching] in the 1970s and 1980s;" that his 1982 book was "referred to more widely than the work of any other practitioner writing in the 1980s;" and "[T]here is no question of Gumperz's extremely positive

\footnotetext{
* My sincere thanks to my two informants from Ziljska Bistrica, and to the meticulous anonymous reviewer who made many very useful comments.
} 
influence on [codeswitching] research." Moreover, two books on sociolinguistic theory (Figueroa 1994, Murray 1998) both praise Gumperz's contributions very highly.

A re-examination of Gumperz's conclusions, and the descriptions and the data upon which they are based - if, as I maintain, these are faulty - is therefore in order. As for his data: it is important, if they are to be cited, that they be cited accurately.

\section{Location and fieldworkers}

Gumperz (1982) relies on extensive Slovene/German bilingual data in Chapters Two "Social Network and Language Shift" and Three "Conversational Code-Switching." He does not mention the name of the town which provides the data; nor did he do so in the report and the article which preceded it, Gumperz $(1975,1976)$. I find this odd: in his other writings of that time he mentions Khalapur in India, Hemnesberget in Norway, and his other fieldwork locations. The best clue to the location of the data is the sentence: "located ... a few miles away from the Yugoslavian and Italian borders" (1982: 44). However, in an even earlier article he does talk about a "pilot study" conducted in 1970 in "a second bilingual area along the Austrian-Yugoslav border[,] Feistritz ... " (1972: 149). Putting aside the fact that this town is closer to the Italian than to what was the Yugoslav border, we can be certain that this was the locality for follow-up fieldwork, because Gumperz, mentioning a previous "detailed ethnographic study," cites Brudner's doctoral dissertation (1969). The last-named explicitly derives from data collected during fieldwork in ZB, and gives details of Brudner's stay in 1967-1968, when, incidentally, she was clearly working on her own (1969: 16-21). In a later article she reports (1972: 54) that she worked in the field both in 1967-68 and again in the summer of 1969 "with Dr. John Gumperz and Mrs. Sarah Russell."1

Who collected Gumperz's data? He reports: "Sarah Wickander assisted in the collection of conversational examples" (1975: D3, note); and "[T]he data on village speech was collected, in large part, by Sarah Wickander" (1976: 20). ${ }^{2}$ In his book the fieldwork is described in a way which suggest that the data should be trustworthy:

The data were collected over a period of several years in South Western [sic] Austria by anthropologists and linguists who lived in local homes and participated in everyday work and leisure activities, studying the verbal and nonverbal etiquette which governs residents' behavior towards kin, friends, colleagues and strangers (1982: 40).

He cites Brudner (1972), but does not acknowledge any linguistic assistance from her.

${ }^{1}$ In her acknowledgements to her dissertation Brudner writes that Gumperz "very generously encouraged my interest in bi-lingualism," (1969: ii). He was not on her supervisory committee. There is an inconsistency in the dates: Brudner writes of working with Gumperz in 1969; Gumperz refers to a pilot study of 1970 and "an initial two-month period of exploratory fieldwork followed after a hiatus of a year by fifteen months of additional fieldwork" (1982: 40); maybe this refers to Brudner's stay in ZB. ZB also has one of the strongest surviving traditions of summer-pasturing for Carinthia (even though the tradition is even stronger elsewhere), cf. Minnich 1988; this fits in with one of Brudner's main conclusions.

${ }^{2}$ The "Sarah Russell" mentioned by Brudner was presumably the married name of Sarah Wickander. 
Gumperz also cites Gamper (1974). Gamper, a native of Šmohor/Hermagor, did his fieldwork in that town and in the village of Pazrije/Passriach in June-August 1973; the two localities are, respectively, 20 and $15 \mathrm{~km}$ up the Zilja/Gail valley from ZB. Gamper's linguistic knowledge is not described (though it is implicit in his thesis (1974) that he understood little Slovene), but this is unimportant, since he was not involved in the sociolinguistic fieldwork in $\mathrm{ZB}$; his is an analysis of the influence of tourism on native culture ${ }^{3}$ and ethnic relations further up the valley.

It is unclear who, of the people mentioned, was responsible for the published linguistic data; and readers are not informed how much or how little Slovene (standard or dialect) Sarah Wickander and/or John Gumperz and/or Lilyan Brudner understood and spoke. From the data, as is apparent below, even though some errors in the Slovene dialect forms are in part identified correctly, it appears that nobody involved in collecting or reporting Gumperz's data was more than minimally competent in the dialect of $\mathrm{ZB}$ [henceforward, Bistriško] or Standard Literary Slovene [SLS] or, indeed, in any Slavic language.

Brudner, for instance, offers no data in her dissertation (other than one song in "Windisch", 1969: 269-272), although she frequently refers to and describes "case studies" where one or another language is used. In August 1998 I asked at the town Gemeindeamt where she had stayed, and was directed to a certain house. There I was told that she had lived altogether over a year in the town; when I asked how much "Windisch" she had understood, they said that "she spoke it very well." Later she writes of "the original two years' research in Feistritz" (Brudner and White 1997: 203). She is however explicit about the extent of her linguistic competence: she learned some "Windisch" in the town (1969: 17) but had to have her Bistriško data (which, I presume, she recorded instrumentally) translated (1969: 11). She writes, however, "I am not able to speak [it] fluently myself," which suggests at least some competence. After over a year (if not fifteen months? two years?) in the town, we should however expect more than "some" competence from a fieldworker interested in language: maybe she was being modest.

How reliable are the data? Let us inspect them now.

\section{The data and phonological commentary}

Gumperz's printed text (1982, chapter 3, pp. 38-58) is taken virtually verbatim from the earlier Gumperz (1976); indeed, with some minor changes, the whole of this chapter is the same as that version. The 1982 book includes some of the errors from the earlier version which are left intact; for example:

"Du must mitgen (you have to come along) u Vlak (to Villach)."

The shift to Slovenian here suggests that the destination, Villach, is treated as old information in contrast to the latter part of the message which is new," (1976: 8)

${ }^{3}$ Gamper deals with "overt cultural features such as house styles, residence patterns, dress styles, and language" (1974: 5). The most important "ethnic relation" in his study is what he calls "the Windisch ethnicity" of Passriach and the role of boundaries in its traditional maintenance and its recent loss; "Windisch" being the local German term for Slovene-speakers (see Priestly 1997), language is a vital component of his study, and the linguistic situation is indeed described clearly and in a way which agrees with what is known elsewhere in recently-Germanized parts of Carinthia. 
Since the place-name is mentioned last, the sentence should read "in contrast to the former part of the message;" the simple correction is not made in 1982: 48. Another example: the word schriftsprache is typed (1976:16) as schiftsprache; this is not corrected in the printed book (1982: 55).

Some errors in the 1976 version are however properly corrected in 1982, e.g., in (4), (6), (8) [see below]. Also, the transcription is changed slightly, namely to one that uses fewer diacritics, but which twice, and correctly, uses the symbol $[\beta]$ for the bilabial fricative though far from consistently, see my commentary in 3.1. However, there are also - instances where the 1976 typed version has been changed and for the worse. See (7), where the word for "today" occurs twice. In 1976 it is incorrectly written as nis both times (1976: 13). In the book, it is changed to ni the first time it occurs, and to nir the second time (1982: 15). The correct form is $\overline{\text { ncos. }}$

The data and some of the paragraphs describing the sociolinguistic situation in this part of Carinthia in the 1976 version are found, in embryonic form, in the typed laboratory 'working paper' (Gumperz 1975). This is clearly a preliminary version, with mis-spellings even in the German data (ya di mit kerbo lan - note the space - for ya di mit kerbəlan, 1975: B10); some incorrect data in this report, omitted from the 1976 version, are used in the 1982 book and are corrected in the latter (e.g., ucera (1975: B6) is correctly changed to učera (1982: 76). One manifestly incorrect sentence in the 1975 version has no fewer than ten correct changes made in 1982, namely (16). However, the 1982 book is inconsistent: e.g., in (15) it presents two corrections to the 1975 version, one of which is an improvement, one of them the reverse. The 1975 laboratory report is not further analyzed or cited here.

I checked all the data, in 2000 and in 2003, in interviews with two male native speakers of Bistriško born in ZB in 1956 and 1954 respectively. They both grew up there, and their family homes are still there.

\subsection{General comments on phonetics and phonology}

Gumperz's phonological transcription is inadequate; my corrections must however be considered as preliminary. The phonetics and phonology of Bistriško were the subject of on-the-spot fieldwork by Viktor Paulsen in the 1930s, but - apart from the notes made for the Slovenski Lingvistični Atlas by Ivan Grafenauer in $1960^{4}$ - have not been analyzed since then. Paulsen's analysis was described to me as a model for its time, ${ }^{5}$ and since he was Troubetzkoy's student this is very likely, but it deals mostly with diachrony and the synchronic descriptions are very short; the sections on phonetics have never been and should be checked. Grafenauer was born in Veliki vas/Micheldorf, which is $22 \mathrm{~km}$ to the east of $\mathrm{ZB}$, and was primarily a scholar of literature and ethnography; again, his data should be checked. Other analyses of the sound systems of Zilja dialects are from Potoče/Potschach in the upper reaches of the valley, very close to Veliki vas (Logar 1968, 1981) and from Marija na Zilji/Maria Gail, near where the river debouches into the Drava/Drau and $26 \mathrm{~km}$

\footnotetext{
${ }^{4}$ I am very grateful to the anonymous reviewer of the first draft of this article, who brought this to my attention. I have not had recent access to the kartoteka for the SLA.

${ }^{5}$ This information came from Ludwig Karničar at a time when he was working on the inventarization of Carinthian Slovene dialect data for the project launched in Graz in the 1980s; see Hafner and Prunč 1982: 68-72 for sources then available for the Zilja Valley dialects.
} 
west of ZB (Lausegger 1989); also in the Koroško dialect area is the Kanalska dolina/Val Canale (see Logar 1971), which is even closer geographically (Žabnice/Camporosso is $13 \mathrm{~km}$ from $\mathrm{ZB}$ ). Because of the distances and the topography, we may not assume that any of these are relevant to the sound system of $\mathrm{ZB}$. The phonetics and phonology of Bistriško are therefore in urgent need of a reliable analysis and the following comments are no more than tentative.

a. The diphthongs written by Gumperz as "ea," "oa" and "ie" would be more accurately shown as "eə", "oə" and "iə"; note that Gumperz uses the schwa as the second element in "uə". I use the schwa throughout for "iə", "uə"; the other two diphthongs are rewritten " $\varepsilon \rho$ ", see $\underline{b}$. below.

b. The use of the circumflex accent on vowels in (4), (6) and (7) is not explained. This dialect has, according to Paulsen (1935), both distinctive pitch and length; perhaps the diacritic mark was meant to indicate one or other of these. Paulsen gives the following vocalic inventory for Bistriško (1935: 44-45): long stressed, rising and long falling: /i เә е $\varepsilon$ a $\supset$ o uə u/; short stressed $/ \varepsilon \partial$ a $\partial /$; unstressed $/ \partial \mathrm{a} /$. I have restricted my own transcription to these symbols, thus correcting, e.g., reakwa to rekwa; although I detected a slight off-glide in my two informants' speech here and with respect to other instances of mid-vowels, the sessions were not extensive enough for certainty, and I rely on Paulsen. I show no length or pitch distinctions, and show stress only on proper names.

c. Most serious, since it shows confusion between contrasting phonemes, is Gumperz's use of "v", " $\mathrm{b}$ " and " $\beta$ ". The latter letter he uses twice-in (16), "naßásan" and (18) "vinarca yə ßoa". In both places it corresponds to a [b] in Central and Eastern Carinthian dialects, cf. Sele [nabásat] "to load" and [jo bíwa] "she was." The same consonant is expected in other forms of the verb "to be", thus the auxuliary in (6), where he uses "v": "we will write" voma ... sríbalə; in (15), where he again uses "v": "there was" yə viu; and in (16), where he uses "b": "it will not come" nčeabə prišu. It is also expected in the word for "ask", in (15): cf. Sele [sam barawa] "I asked," for which Bistriško is definitely not "sn varaua". An etymological */b/ also occurs as first consonant in the word for "wrinkles," vaudə in (15), and as the intervocalic consonant in "write" šriba- in (6), (7). Paulsen lists the phonemes $/ \mathrm{b} \mathrm{d} \mathrm{g/} \mathrm{for} \mathrm{all} \mathrm{Zilja} \mathrm{dialects,} \mathrm{and} \mathrm{states} \mathrm{that} \mathrm{phonet-}$ ically these are realized variously ("fakultative Varianten") as stops [b d g] and as fricatives [ $\beta \delta \gamma]$ : in the Western sub-dialects of the valley they occur as fricatives more frequently, in the east (including ZB) less frequently. Only in postvocalic word-final position do fricatives always occur, and this is true for all Zilja dialects; in ZB and other eastern dialects the fricatives occur "relativ selten" in other environments (1935: 47-48). Diachronically, the modern /b/ derives both from Proto-Slavic $* / b /$ in all positions, and from */v/ before front vowels and before $/ 1 /$; and in loans corresponding to Contemporary German /b/ and /v/. Elsewhere, Proto-Slavic */v/ > [w], and [w] also derives from */1/ in all environments, $(1935: 151,166)$. Phonologically, then, we have two voiced labials: /b/ which occurs phonetically as $[\mathrm{b}]$ and/or $[\beta]$; and $/ \mathrm{w} /[\mathrm{w}]$. For the former I heard [ $[\mathrm{B}]$ from my 
informants on several occasions, e.g., [u ßlak] "to Villach" in (1), [praßəm] "I say" in (4) and [Blikə] "many" in (10). Note $[\beta]<* / \mathrm{v} /$ in these examples, two of them preceding an $/ 1 /$, the other preceding an original front /i/. In the corrected versions of the data I arbitrarily write " $\beta$ " rather than "b" in all appropriate environments, given the persistence of the fricative pronunciation in my own observations, 30 years after Gumperz's fieldwork and 70 years after Paulsen's comments, and to draw attention to the occurrence of the fricative pronunciation. I use neither $/ \delta /$ nor $/ \gamma /$; I have not heard these, either from the two informants mentioned, or in visits to ZB.

d. The change $/ \mathrm{m} />/ \mathrm{n} /$ in word-final position has been long known as characteristic of dialects in this region. I heard $/ \mathrm{n} /$ in [sən] "I am" [praßən] "I say" and [žinjən] "I think" extremely frequently from my two informants, but on a very few occasions did hear a prepausal [m]; this I ascribe to the influence of SLS, both speakers having had post-secondary education at the Slovenska Gimnazija in Celovec. In the transcriptions I write $\underline{\mathrm{n}}$ consistently except where the following word begins with a labial consonant and a pause between words is unlikely, as in (4).

e. The glides are variously rendered as, respectively, $\underline{\mathrm{i} \sim \mathrm{j} \sim \mathrm{y}}$ and $\underline{\mathrm{u} \sim \mathrm{w}}$. I use $\mathrm{j}, \underline{\mathrm{w}}$.

f. The non-initial combinations "əm", “ən", "əl”, "ər" in preconsonantal and word-final position may phonetically be syllabic resonants, thus "sən" [sn]]; Instrumental analysis may be required to clarify this. For post-pausal position, I clearly heard syllabic resonants, hence the transcriptions "mpa" [mpa] and "ntər" for what may be [ntr] or [ntər].

g. Geminate consonants at word-boundaries, where no pause intervenes, are often degeminated; in $(15,21)$ I write [jəs sən] rather than [jəsən] for morphological clarity.

Gumperz is inconsistent, also, in his transcription of the German data. For example, $/ \mathrm{v} /$ is sometimes written according to the orthographic standard " $\mathrm{w}$ " (2: werst mə wos brinn) and sometimes as "v" (18: fon vin vor si). I make no changes to the German.

\subsection{Data}

The data from Gumperz (1982) are cited in the order they occur in that publication, with references to the 1976 article where relevant. Capital letters are replaced with lower-case. For ease of cross-reference, the citations are numbered. The first line presents the linguistic data: Bistriško forms are underlined, German forms not so. The second line is the translation provided; the translation of the Slovene is underlined, the translation of the German not so. Any item in Slovene and German preceded by a check mark is considered correct except for inadequacies in the phonological transcription; any translation preceded by a check mark is likewise judged to be correct. Comments on and corrections to errors follow in italics. In this section, corrections with respect to the points made in 3.1. above are made without further comment. Finally, although I am confident in the corrections I make here, I also emphasize that only a complete analysis of this dialect can produce definitive transcriptions. 
(1) $\quad \checkmark$ du must mitgen $\underline{\mathrm{u} \text { vlak }}$

$\checkmark$ You have to come along / to Villach (1976: 8, 1982: 48)

(Correct: $\underline{\mathrm{u} \text { Blak) }}$

(2) $\checkmark$ peidə werst mə wos brinn come here / go and get something for me (1976: 8, 1982: 48)

("Come here" would be pridə sən; peidə means "go". Correct: pejdə)

(3) $\checkmark$ murəš fain paledatə na suəx you'll have to look well / go look (1976: 8, 1982: 48)

(The German means literally "well then, look". Correct: muərəš fajn palsdatə)

(4) $\checkmark$ pa yəs prabəm profêsaryə puəšlə sn reakua: und gerade hoite həbən si miəsən nox fak fuərən

$\checkmark$ and I say to the professor, then I said / and just today they had to go to Fak (1976: 9, 1982: 48)

("Fak" is presumably the town of Faak am See/Bače. Correct: pa jəs praßəm profesarjə puəšlə sən rekwa)

(5) pasluši stei s maksan šua učera təkə reakwa: also dos sind 250 šilin folt auf oxte totə dənar na zad

now Max and I said this yesterday / O.K. that's 250 schilling to be split among eight / that money is not to be returned (1976: 9, 1982: 49)

(pasluši means literally "listen"; for a translation I suggest "Listen now ...” stej is the Bistriško equivalent of SLS zdaj. More important: the last phrase is not negative, and means "that money [is to be] returned;" and the $1^{\text {st }}$ dual past auxiliary is /sma/ not /šua/. Correct: pasluši stej s máksan sma učera təkə rekwa... to tə dənar nazad).

(6) von príšwa kə $S$ papûnə pa voma muu sríbalə

$\checkmark$ I will go to $\mathrm{S}$ in the afternoon and we will write a little

(Note: "a little" is məw. Correct: ßon prišwa kə S papunə pa ßoma məw šrißalə)

(7) mpa koi stə vi ni dêwalə ... mi sma niə šribalə

$\checkmark$ and what did you two work today / we two wrote today (1976: 13, 1982: 52)

(The conjunction mpa is normally explained as deriving from *in pa; given contact in this area with Friulian and Romance, some interference from ma may perhaps be considered. "Today" is nco (cognate with SLS nocoj); the forms bi, mi are the grammatically incorrect plural forms, as properly noted by Gumperz; the correct dual form would (in both numbers!) be mədwa. Correct: mpa koj stə Bi nco dewalə ... mi sma nco šrißala)

(8) $\checkmark \checkmark$ an gre $\mathrm{z}$ možan ... an gre $\mathrm{z}$ móžamə

$\checkmark$ he goes with the man ... he goes with the men $(1976: 13,1982: 52)$

(Note: the data are, except for small vocalic details, correct, but Gumperz 
identifies the case of the prepositional phrases as "dative". Correct: an gre z možan ... an gre z možamə)

(9) sən pr totlan špórtlariə sadewa ... pr totlax špórtlariat ... špórtlarian

I sat near those athletes (1976: 14, 1982: 52-53)

(This item requires detailed citation and discussion. Gumperz cites the first version, pr totlan špórtlaria, and continues:

"Her mother corrected, giving the right ending: pr totlax špórtlariat (locative plural). Another young girl who heard the first girl's tape substituted športlarian (using the dative plural ending), which is also wrong." (1982: 52-53)

There is both error and confusion here. (a) Both my informants categorically rejected the $/ l /$ in totlan and totlax. (b) Both also said that they had never heard any villager use a final -t, as in the cited "correction." The locative plural final /-x/ is so ubiquitous in all Slavic dialects that a final /-t/ was (if heard correctly) surely a slip of the tongue, especially given the occurrence of $/ x /$ in the adjective preceding the noun. (c) por totan špórtlarjə is a reasonable transcription - not incorrect! - for the locative singular. What Gumperz should have noted, then, was the daughter saying the correct Bistriško for "I sat near that athlete" and her mother correcting it to the correct Bistriško for "near those athletes." The third version was indeed a grammatical error, the use of the dative plural for the locative plural of the noun. ${ }^{6}$ Corrected, therefore: son por totan špórtlarjə sadewa ... pər totax špórtlarjax ... špórtlarian. Since Gumperz's point here is the use of incorrect grammatical forms, accuracy in his own transcription and in his grammatical comment was essential, but was in several respects lacking.

(10) $\checkmark$ vlikə trúək

$\checkmark$ many children (1976: 14, 1983: 53)

(Correct: Blikə trúək)

(11) $\checkmark$ čompe... čompə

$\checkmark$ potatoes (1976: 14, 1982: 53)

(12) uzeymas ti kafe? oder te?

$\checkmark$ will you take coffee? or tea? (1982: 60)

(Note the 2nd person singular verbal ending; correct: uzejmaš ti kafe?)

(13) $\checkmark$ pa prawe wen er si nit colt gib i si nit then he said / if he does not pay for it, I will not give it (1982: 76)

(Note: "he says" rather than "he said." Correct: pa praße)

(14) $\checkmark$ pa vaguta jə tudi reku mənə učera also a hektar hob i gel also i bin

${ }^{6}$ Interestingly, research into language-simplification among young speakers of other Carinthian Slovene dialects, carried out by David Stermole and myself in 1985, showed similar (though unsystematic) "errors" with respect to oblique case-forms of nouns occurring with prepositions (dative for instrumental with "z", "za", "pod", "pred" and instrumental for locative with "pr"), see Priestly (1988: 69-71). 
gewilt

$\checkmark$ and Vaguta has also said to me yesterday / so I have about a hectare, so I am willing (1982: 76)

(The male surname is stressed on the second syllable: vagúta).

(15) tədei yə viu ... tolə tudi tolə yə... prou vaudə yə mou pa yəs sn varaua rainaryə yas sn reakua is etwas kešvolən ... praba nain er is gut ernert et hot kain vosar unt guar niks

$\checkmark$ then there was also ... there was ... he actually had wrinkles and I asked [Dr] Rainer, I said: Is something swollen. He says, No he is well nourished he has no water or anything (1982: 76)

(Note the misspelling of the $1^{\text {st }}$ person pronoun; also the inconsistency, praba in this item and prawe in (13). Correct: tədej jə Biw ... tolə tudi tolə jə... prow ßawdə jə mow pa jəs sən ßarawa rajnarjə jəs sən rekwa... praßə $\ldots)$

(16) nčeabə prišu vo ki šu vaitar ... ya ki təkə naßásan zapkamə pa yə žiə ciu štəm yə pastranə regən vert so ain vint is drausən

$\checkmark$ it will not come, it will pass by ... it is so overloaded with apples and the entire tree is bent already, it will rain it is so windy outside (1982: 77)

(Several inaccuracies: vo for bə, šs for šsə, ya for jəo, štəm for šstom; the prepositional phrase $\mathrm{z}$ apkamə is written as one word. Bistriško ki corresponds to the -koj in SLS takoj and is here used similarly to SLS kar. Corrected: nčєßə prišu ßə ki šwə vajtar ... jə ki təkə naßásan z apkamə pa jə žiə ciw štom jə pastranə.)

(17) $\checkmark$ grta yətə ja so ist das

$\checkmark$ go there (1982: 78)

(Correct: gərta jətə)

(18) totə kə yə uanə mewa kuarbcə / kə yə ušə mewa / koi yə mewa / təšə kuarbcə pa ušə yə mewa / no na žinian /ya ya di mit kerbəlan / binarca yə Boa / na di mit di kerbəlan / ya binarca / ya / fon vin vor si ?

the one who last year had baskets / the one who had lice / what did she have? / such baskets and she had lice /I don't believe it / yes yes the one with the baskets / she was from Vienna / no the one with the baskets / yes from Vienna / yes / from Vienna she was? (1982: 78-79)

(The phrase no na žinian is probably to be amended to to no žinian with the meaning "I don't think so". Corrected: tota kə jo wanə mewa kuərbcə / kə jə ušə mewa / koj jə mewa / təšə kuərbcə pa ušə jə mewa / to nə žinjan ... / Binarca jə ßoa ... ja ßinarca, ja.)

(19) alə mormaya təkə nadritə dann von etwas is, nə guət. pa tolə gax wikolna kost sibn oxthundert šiling / ja ja payə dənar tau / yəs sak leta diən oli ntər. kost virzen šiling

OK let us do it like this / then if something happens OK fine / if sometimes the motor must be rewound / it costs seven or eight hundred schillings... OK OK then the money is there / I put in oil every year. It costs 
fourteen shillings (1982: 80)

(Note incorrect segmentation of mormaya. sak is apparently infrequent; more usual is usak. A more likely version of the German for "if something is wrong, i.e., happens" is vo etvos is. The phrase tolo gax wikolna means "that [motor] [is to be] immediately rewound". Corrected: a morma jə təkə nadritə ... pa tolə gax wikolna ... ja ja pa jə dənar tam ... jəs usak leta diən oli ntər)

(20) vigələ ma yə sa americə / kanada pridə / kanada mus i sogn nit

Wigele got them from America / it comes from Canada / I would not say Canada (1982: 80)

(Several errors in these seven words. The spelling of the surname is "Wiegele"; "them" is jox; "from America" is z američa; "from Canada" is ut kanada or s kanada. The German "mus $i$ sogn nit" would be better translated as "I shouldn't say." Corrected: vígələ ma jox $\mathrm{z}$ američə / ut kanadə pridə ...)

(21) yə sn y utrə stawa yo sn traktor startawa npa sn wizn nawarəwa

I got up in the morning, I started the tractor, and then I turned the grass (1982: 91)

(This item is the most error-prone of the collection. The Bistriško for the English gloss would be: jas sən zjutro stawa jas sən traktor štartawa mpa sən trawə aßračəwa. The first two words of Gumperz's version are in fact probably correctly spelled, see 3.1.g. However, the Bistriško for "in the morning" is incorrect; the past form of "start" is spelled in the German style with " $s$ " instead of " $s$ "; and, according to both informants, the use of the German wizn (Standard Wiesen) "meadow" is very unusual and the last word, nawarowa, is meaningless. Is it perhaps be a mistakenly-noted "nabasawa", i.e., "loaded"?)

(22) yo sn šu lo kaiserya pa nye siedu erix česaryu pa karli yanaxu mpa frantsi mimayu pa sma vinawa pilo

I went to Kaisers and there sat Erich of the Cesar family, Karl of the Janach family and Franz of the Mimi family and we drank some wine (1982: 91)

(Both the Bistriško and the English require several corrections. "Kaiser" was the name of an inn: "I went to Kaiser" would be sən šu da kájsərja or sən šu kə kájsərju. The lo is spurious; perhaps it is a misreading of a poorly-handwritten $\mathrm{k} \ni$ ? "Čezarju", "Janahu" and "Mimiju" are not family names but household names; as elsewhere in the Slovene lands, these names are adjoined to first names to identify individuals. The Bistriško therefore (with emendations to the phrases for "there sat" and "we drank some wine") would be something like: jəs sən šu da kájsərja pa tan je sjzdu čéžarju érix pa jánaxu kárli mpa mímaju fránci pa sma Binə pilə. An alternative for "there sat", preferable to the $3^{\text {rd }}$ singular of the attempted verb in Gumperz's gloss, would be the $3^{\text {rd }}$ plural: sa sadelo. A better English translation would be: "I went to the Kaiser [inn] and there sat Čezar's Erih, Janah's Karl and Mimi's Franc, and we drank [some] 
wine", with an explanation that, e.g., "Čezar's Erih" was the Erih who lived at the house (or farm) known as "Čezar's".

There are, clearly, numerous errors in the Bistriško and/or the German data, and in many of the translations into English. Some errors are extremely serious. I will not discuss here potential reasons for these errors. In some respects the data show a close approximation to the dialect of $\mathrm{ZB}$; in others, they do not. What is most striking is the inconsistency.

\section{Conclusion}

It is no understatement to conclude that Gumperz's data are replete with errors. We are left with a puzzle: how could descriptions deriving from fieldwork carried out in association with Lilyan Brudner, who seems to have had some competence in the dialect, have so many mistakes? Was it Gumperz who collected the data which we read in his articles and book, with some (but insufficient) help from Brudner and Wickander/Russell, and was it Gumperz on his own who finished the transcriptions? And in any case, why did he not ask a colleague in the Slavic Department at the University of California at Berkeley to check them for him? Even a speaker of, say, Russian, would have noticed the poor segmentation of, e.g., zapkama for "with apples" in (16).

Let me now cite Gumperz himself, who extols the advances made by American empirical linguists thus (1982: 23):

"Since language choice is largely subconscious, and since the signaling of social information is crucially dependent on context, the study of social meaning requires fieldwork techniques capable of challenging the verbal skills employed by speakers in everyday interaction."

The fieldworkers in Zilska Bistrica could hardly have "challenge[d] the verbal skills employed by" the local speakers; on the evidence of the data, they were not properly competent in the language-variety that many of the people in the community spoke much of the time. Linguists who deal with Slovene, and especially those involved in Carinthian Slovene, can only lament the fact that Gumperz's data have hitherto been accepted as valid.

\section{Bibliography}

Brudner, Lilyan Lois Amdur. 1969. An Analysis of the Ethnic Component of Social Transactions. Ph.D. Dissertation, University of California at Berkeley, Anthropology.

- -. 1972. "The maintenance of bilingualism in Southern Austria," Ethnology 11: 39-54.

- - and Douglas White. 1997. "Class, property and structural endogamy: visualizing networked histories," Theory and Society 26: 161-208.

Eastman, Carole, ed. 1992. Codeswitching. Clevedon: Multilingual Matters.

Figueroa, Esther. 1994. Sociolinguistic Metatheory. Oxford: Pergamon. 
Gamper, Josef A. 1974. The Influence of Tourism on Ethnic Relations in Southern Austria. M.A. Thesis, Department of Anthropology, California State University, Hayward CA.

Gumperz, John J. 1972. "The communicative competence of bilinguals: some hypotheses for further research," Language in Society 1: 143-54.

- -. 1975. "Code switching in conversation," Pragmatics Microfiche 1/4: A2-D4.

- -. 1976. "Social network and language shift," in Papers on Language and Context, eds. Jenny Cook-Gumperz and John J. Gumperz, Working Paper no. 46, University of California Language Behavior Research Laboratory.

- -. 1982. Discourse Strategies. Cambridge: Cambridge University Press

Grenoble, Lenore A. 1995. "Future directions in Slavic linguistics," Journal of Slavic Linguistics 3/1: 1-12.

Hafner, Stanislaus and Erich Prunč, ed. 1982. Schlüssel zum "Thesaurus der slowenischen Volkssprache in Kärnten". Vienna: Verlag der Österreichischen Akademie der Wissenschaften.

Heller, Monica, ed., 1988. Codeswitching. Anthropological and Sociolinguistic Perspectives. Berlin: Mouton de Gruyter.

Lausegger, Herta. 1989. “Značilnosti slovenskega govora pri Mariji na Zilji,” 137-148 in F. Jakopin, ed., Zbornik razprav iz slovanskega jezikoslovja: Tinetu Logarju $o b$ sedemdesetletnici. Ljubljana: Inštitut za slovenski jezik Fran Ramovš ZRC.

Logar, Tine. 1968. "Vokalizem in akcent govora Potoč v Ziljski dolini," Zbornik za filologiju i lingvistiku 11: 137-143.

- -. 1971. "Dialektološke študije XV: Govor Slovencev v Kanalski dolini," Slavistična revija 19: 113-123.

- -. 1981. "Potoče (Potschach) OLA 146," 183-193 in Pavle Ivić, ed. Fonološki opisi srpskohrvatskih/hrvatskosrpskih, slovenačkih $i$ makedonskih govora obuhvaćenih opšteslovenskim lingvističkim atlasom. Sarajevo: Akademija nauka i umjetnosti Bosne i Hercegovine.

Milroy, Lesley. 1980. Language and Social Networks. Oxford: Blackwell.

- -. 1987. Observing and Analysing Natural Language: A Critical Account of Sociolinguistic Method. Oxford: Blackwell

- - and Pieter Muysken. 1995. One Speaker, Two Languages. Cross-Disciplinary Perspectives on Code-switching. Cambridge: Cambridge University Press.

Minnich, Robert G. 1988. "Speaking Slovene - Being Slovene: Verbal codes and collective self-images. Some correlations between Kanalska dolina and Ziljska dolina," Slovene Studies 10/2: 125-147.

Murray, Stephen O. 1998. American Sociolinguistics. Theorists and Theory Groups. Amsterdam: Benjamins.

Myers-Scotton, Carol. 1993. Duelling Languages. Grammatical Structure in Codeswitching. Oxford: Clarendon.

Paulsen, Viktor. 1935. Lautlehre des slovenischen Gailtalerdialektes in Kärnten. Diss., Universität Wien. 
Priestly, Tom. 1988. "Accelerated grammatical change in Carinthian Slovene: Dialect mixture, or "linguistic decay?" Canadian Slavonic Papers 30: 62-80 [= Canadian Contributions to the $X$ International Congress of Slavists, Sofia 1988].

- -. 1997. "On the development of the Windischentheorie," International Journal of the Sociology of Language 124: 75-98.

- -. in prep. "Setting the record straight: John Gumperz on Slovene in Austria."

Wardhaugh, Ronald. 2002. An Introduction to Sociolinguistics. 4th ed., Malden MS/Oxford: Blackwell.

Prispelo novembra 2004, sprejeto januarja 2005

Received November 2004, accepted January 2005
Tom Priestly Alberta, Canada 